\title{
Records of rove beetles (Coleoptera, Staphylinidae) from Gran Sasso and Cilento protected areas in Central and Southern Apennines (Italy)
}

\author{
Riassunto: Reperti di Coleotteri Stafilinidi provenienti da aree protette del Gran Sasso e del Cilento, nell'Appennino centrale e meridionale \\ (Italia). \\ Gli Autori forniscono un elenco di 54 specie di Stafilinidi del Parco del Gran Sasso e del Parco del Cilento nell'Appennino centro-meridionale. \\ I Coleotteri sono stati campionati mediante trappole aeree (window traps) nel 2013 e 2016 in aree delle quali sono riportati i caratteri generali \\ e le caratteristiche botaniche. Per ogni specie sono forniti dati distributivi ed ecologici. Atheta taxiceroides, Eusphalerum martinae, Philonthus \\ mannerheimi, Quedius latialis, Q. riparius and Q. truncicola sono le specie più notevoli dal punto di vista faunistico ed ecologico.
}

\begin{abstract}
A list of 54 Staphylinid species from Parco del Gran Sasso and Parco del Cilento in the central-southern Apennines (Italy) is given. They were sampled by window flight traps, in 2013 and 2016, in areas for which general and botanical features are reported. For each species, distributional and ecological data are included. Atheta taxiceroides, Eusphalerum martinae, Philonthus mannerheimi, Quedius latialis, Q. riparius and $Q$. truncicola are the most remarkable species from a faunistic and ecological point of view.
\end{abstract}

Key words: Coleoptera, Staphylinidae, Italy, Apennines, Parco Nazionale del Gran Sasso e dei Monti della Laga, Parco Nazionale del Cilento, Vallo di Diano e dei Monti Alburni, Records, Saproxylic species.

\section{INTRODUCTION}

The faunistic knowledge of the Italian Staphylinidae, the largest family of Coleoptera (more than 60,000 described species, Zanetti, 2015) is still largely imperfect. The Apennines were surveyed carefully in some areas and for some groups (Sabella \& Zanetti, 1991; Tagliapietra \& Zanetti, 2003; Zanetti \& Tagliapietra, 2005), but many areas are still very imperfectly known as can be detected by the density of records in Zanetti (2005) where, despite the important efforts of entomologists like Fernando Angelini (Francavilla Fontana, Brindisi) many areas are scarcely "covered". The monitoring that has produced the records of the present paper, even if partial, contribute to the increase of the basic knowledge of the group in peninsular Italy, essential for any ecological study. This paper is to be considered as preliminary to a following quantitative analysis of the records.

\section{Study AREA}

The data here presented were collected within the context of the restoration project LIFE+ 'FAGUS'
(11/NAT/IT/135, www.faguslife-project.eu), and represent the information baseline that will be used to monitor the effects of the project's concrete conservation actions. The project focused on two habitats of European priority interest according to the EU Habitats Directive (92/43/EEC) i.e., the habitat 9210* Apennine beech forests with Taxus and Ilex, and the habitat 9220* - Apennine beech forests with Abies alba and beech forests with Abies nebrodensis. Data were collected in six European beech forests (Fagus sylvatica) located in the Apennines, within two Italian national parks. Three areas are located in central Italy, within the "Gran Sasso and Monti della Laga" National Park (hereafter "Gran Sasso PNGS"). The remaining three study areas are located within the "Cilento, Vallo di Diano and Alburni" National Park (hereafter "Cilento PNC"), in southern Italy. The sampling sites are here listed, with the coordinates of each: PNGS:Teramo Prov., Crognaleto, Incodara, $1400 \mathrm{~m}$ a.s.1., 42.5123 N, 13.4735 E

Teramo Prov., Prati di Tivo, Pietracamela, 1500 m a.s.1., $42.5096 \mathrm{~N}, 13.5679 \mathrm{E}$

\footnotetext{
*Adriano Zanetti, Museo Civico di Storia Naturale, Lungadige Porta Vittoria 9, 37129 Verona, Italy. E-mail: adriano.zanetti50@tiscali.it

${ }^{* *}$ Francesco Parisi, Dipartimento di Bioscienze e Territorio, Università degli Studi del Molise, Contrada Fonte Lappone, 86090 Pesche (IS), Italy; Dipartimento di Agricoltura, Ambiente e Alimenti, Università degli Studi del Molise, Via de Sanctis, 86100 Campobasso, Italy.

E-mail: francesco.parisi@unimol.it
} 
Teramo Prov., Pietracamela, Venacquaro, 1250 m a.s.1., $42.4988 \mathrm{~N}, 13.5139 \mathrm{E}$

PNC: Salerno Prov., Ottati, Monti Alburni, Rupe di Mezzo, 1350 m a.s.l., 40.5136 N, 15.3292 E Salerno Prov., Corleto Monforte, Monti Alburni, 1300 m a.s.l., 40.4705 N, $15.4317 \mathrm{E}$ Salerno Prov., Teggiano, Montagna della Motola, 1200 m a.s.l., $40.3761 \mathrm{~N}, 15.4694 \mathrm{E}$

General information of the surveyed habitats is in Mattioli et al. (2017).

In both National Parks cows, sheep and goats (quite frequent in the study areas) are present, and also wolf, roe deer and deer, among the wild large mammals. They justify the abundance of coprophil species surveyed.

\section{Parco Nazionale del Gran Sasso e dei Monti della Laga}

Surface: 33,995 ha.

Other protection status: the SCI [ = Site of Community Importance] is overlapped with the SPA [= Specieal Protection Area] "Parco Nazionale del Gran Sasso e Monti della Laga" (IT7110128). Abiotic conditions. The climate of the SCI "Gran Sasso" (IT7110202) can be referred to the Temperate region. The area is located between 807-2912 m a.s.l. The Gran Sasso massif can be divided into two main areas with different orientation and morphology: the first has a rough morphology and extends from the Vomano Valley to the Tavo Valley; the other sector is characterized by hills with a north-south orientation. The alignment in the northern sector includes the highest peaks, such as Corno Grande (2912 m a.s.1.) and Corno Piccolo (2655 $\mathrm{m}$ a.s.1.). The lithological composition of the $\mathrm{SCI}$ area is mainly calcareous and dolomitic. The Quaternary glaciations deeply shaped the morphology of the mountain and left visible traces in the valleys (e.g. "U" profile), and in the glacial cirques. Karst phenomena occur in the areas of Campo Imperatore and Campo Pericoli.

Floristic information: the botanical data comes from the floristic surveys related to the LIFE+ 'FAGUS', some of them are however contained in Mattioli et al. (2017).

Incodaro locality. The floristic list was found to be relatively poor: a total of 52 species were found, none of them of Community interest, with very inconspicuous coverage values. The arboreal layer proved to be always dominated by Fagus sylvatica and Abies alba, with variable relative dominance. Locally Acer pseudoplatanus and Sorbus aucuparia are present. The shrubbery is normally absent.

Relevant species of the herbaceous layer: Actaea spicata, Adenostyles glabra, Brachypodium rupestre, Cardamine bulbifera, C. enneaphyllos, C. heptaphylla, Carex pilosa, Daphne laureola, Epipactis helleborine, Geranium robertianum, Lilium martagon, Luzula sylvatica, Neottia nidus-avis, Polystichum aculeatum, P. setiferum, Prenanthes purpurea, Pteridium aquilinum, Pulmonaria apennina, Rubus hirtus, Ruscus hypoglossum, Sanicula europaea, Viola reichenbachiana.

Prati di Tivo locality. The arboreal layer is always dominated by Fagus sylvatica, locally with Taxus baccata and Sorbus aria, usually limited to the dominated plane. The shrubbery is usually absent, sometimes young individuals of Acer pseudoplatanus, Sorbus aucuparia, Rosa pendulina and Juniperus communis (seedlings) are present.

Relevant species of the herbaceous layer: Adoxa moschatellina, Aremonia agrimonioides, Asplenium trichomanes, Brachypodium sylvaticum, Cardamine bulbifera, C. enneaphyllos, C. heptaphylla, Carex flacca, Cephalantera rubra, Cephalanthera damasonium, Dactylorhiza maculata, Daphne laureola, Epilobium montanum, Epipactis helleborine, Festuca heterophylla, Galanthus nivalis (included in Annex 4 of Directive 92/43 / EEC), Galium odoratum, Geranium nodosum, G. robertianum, Hepatica nobilis, Hieracium racemosum, Lathyrus vernus, Lilium martagon, Luzula sylvatica, Platanthera chlorantha, Polystichum aculeatum, P. setiferum, Primula vulgaris, Pulmonaria apennina, Rubus hirtus, Sanicula europaea, Saxifraga rotundifolia, Sedum magellense, Solidago virgaurea, Viola reichenbachiana.

Venacquaro locality. The arboreal layer is always dominated by Fagus sylvatica, sometimes with Taxus baccata and Ilex aquifolium at dominated plane. Remarkable is the presence of some individuals of silver fir (Abies alba). The shrubbery is usually absent or formed by isolated individuals of Taxus baccata, Ilex aquifolium, Crataegus oxyacanhta, Laburnum anagyroides, Fagus sylvatica, Juniperus communis and Acer pseudoplatanus. 
Relevant species of the herbaceous layer: Adoxa moschatellina, Brachypodium rupestre, B. sylvaticum, Cardamine bulbifera, Carex sylvatica, Cephalanthera damasonium, C. rubra, Cystopteris fragilis, Dactylorhiza maculata, Daphne laureola, Dryopteris filixmas, Epilobium montanum, Epipactis helleborine, Festuca heterophylla, Galanthus nivalis (included in Annex 4 of Directive 92/43/EEC), Galium rotundifolium, Geranium nodosum, Hepatica nobilis, Hieracium racemosum, Hypericum montanum, Lactuca muralis, Lathyrus vernus, Limodorum abortivum, Asplenium trichomanes, Lilium martagon, Listera ovata, Luzula forsteri, L. sylvatica, Platanthera chlorantha, Primula vulgaris, Pulmonaria apennina, Rubus hirtus, Sanicula europaea, Saxifraga rotundifolia, Sedum magellense, Viola reichenbachiana.

\section{Parco Nazionale del Cilento, Vallo di Diano e dei Monti Alburni}

Surface: about 36,000 ha.

Other protection status: the SCI is overlapped with the SPA "Monte Cervati e dintorni" (IT8050046).

The SCI Mount Motola includes a calcareous massif dissected by several ravines. The hilly areas are instead characterized by clay and marl substrata. The limestone structure Mt. Cervati Mt. Motola belongs to the same stratigraphic unit of the Alburni massif (unit Alburno-Cervati-Pollino). Altitude ranges from 600 to $1734 \mathrm{~m}$ a.s.1.. The Mt. Motola is mostly included in the Temperate climatic region, the influence of the Mediterranean climate is strong in the hilly areas, in the eastern part along the Vallo di Diano and in the western part, in the surroundings of the town of Sacco.

Alburni - Ottati locality. In the area of Ottati, 76 species of vascular plants have been found. Arboreal layer dominated by beech (Fagus sylvatica) locally with Acer cappadocicum lobelii, Sorbus aucuparia, Taxus baccata, Ilex aquifolium and Quercus cerris (plantulas).

Relevant species of the herbaceous layer: Allium pendulinum, A. ursinum, Anemone apennina, Aquilegia vulgaris, Cardamine bulbifera, Epipactis helleborine, Galium odoratum, Hieracium racemosum, Lathyrus venetus, Melica uniflora, Moehringia muscosa, M. trinervia, Polypodium interjectum, Pulmonaria apennina, Rubus gr. hirtus, Sanicula europaea, Viola reichenbachiana.
Alburni - Corleto Monforte locality. A total of 61 species were found. Tree layer always dominated by Fagus sylvatica, with Ilex aquifolium, Taxus baccata and sometimes Acer cappadocicum lobelii, Laburnum anagyroides and Sambucus nigra.

Relevant species of the herbaceous layer: Allium ursinum, Cardamine bulbifera, Cephalanthera rubra, Galium odoratum, Lactuca muralis, Melica uniflora, Neottia nidus-avis, Polystichum setiferum, Rubus gr. hirtus, Sanicula europaea, Viola reichenbachiana.

Motola locality. A total of 62 species were found, none of Community interest. The arboreal layer is always dominated by Fagus sylvatica, accompanied by Abies alba, and sometimes by Acer cappadocicum lobelii, A. opalus obtusatum, Castanea sativa and Ostrya carpinifolia and Ilex aquifolium (once only).

Relevant species of the herbaceous layer: Viola reichenbachiana, Anemone apennina apennina, Daphne laureola, Festuca exaltata, F. heterophylla, Geranium robertianum, Lathyrus venetus, Polystichum setiferum, Rubus gr. hirtus and Saxifraga rotundifolia.

\section{Materials AND Methods}

Sampling scheme. The forest structural features and multi-taxon composition were sampled through a non-aligned systematic sampling method. Based on a preliminary field survey, we first defined an area of interest for each study area, i.e. the fraction of the study area where the habitats $9210^{*}$ and $9220^{*}$ of Habitat Directive actually occurred. The total surface of the area of interest across the six study areas was 70 ha. A $100 \times 100 \mathrm{~m}$ square grid was then overlapped to the area of interest, and a sampling plot was randomly located within each cell of the grid completely contained within the area of interest. For two study areas located in Cilento PNC (i.e. 'Corleto Monforte' and 'Ottati'), the sampling design was slightly different, in order to be coherent with the methods applied in a previous project (Blasi et al., 2010; Burrascano et al., 2011). In this case, the sampling plots were located at the nodes of a $500 \times 500 \mathrm{~m}$ square grid. A total of 33 plots were sampled, 19 in the Gran Sasso PNGS and 14 in the Cilento PNC. For each plot, we recorded the topographical position in terms of altitude, slope and aspect (Sabatini et al., 2016).

Saproxylic survey. Forest-dwelling beetles were sam- 
pled using one window flight trap for each plot. The trap consists of two crossed Plexiglas panels, $60 \times 40 \mathrm{~cm}$, under which a funnel with a diameter of $42 \mathrm{~cm}$ is placed, which conveys the arthropods into a polyethylene bottle, with a capacity of $500 \mathrm{ml}$, filled for a third a solution of water and salt. Traps were placed at $1.5-2 \mathrm{~m}$ height above the ground near a tree to intercept the flight of insects; they were then trapped inside a preserving vial containing a solution of water and salt. Since this method does not exert an attraction selective with respect to saproxylic beetles, it was integrated using eclectors (emergence traps). Eclectors were used for collecting saproxylic insects active in deadwood fragments on the forest floor. Depending on the availability of coarse woody debris, up to three eclector traps were set up on deadwood fragments in the first three decay classes. Traps were placed as close as possible to the plot center. Nevertheless, deadwood fragments were not available in all the sampling plots. For this reason, in order to keep the sampling effort constant through the plots in quantitative analyses, these were run only considering the beetles collected through window flight traps ( $\sim 96 \%$ of the captures). The data obtained using the eclectors were only used to provide an integrative description of the beetle assemblages. The monitoring of saproxylic insects took place from June to September 2013 and 2016. Each trap was sampled three times, once every 27-30 days (Sabatini et al., 2016).

\section{RESULTS}

List of species. Nomenclature follows Schülke \& Smetana (2015). Species are listed alphabetically, subgenera are not reported because in many Staphylinid genera (e.g. Atheta) the current subgeneric taxonomy is inconsistent. Ecological data come mainly from Koch (1989), supplemented by unpublished observations. Data are summarized in Tab 1.

Aleochara intricata Mannerheim, 1830

Detection areas: PNC Alburni: Ottati.

Distribution in Italy. All continental Italy and major islands (Zanetti, 1995).

General distribution. Palearctic region (Schülke \& Smetana, 2015).

Habitat. In excrements (Koch, 1989).

Aleochara sparsa Heer, 1839

Detection areas: PNGS Venacquaro; PNC Alburni: Ottati.
Distribution in Italy. All continental Italy and major islands (Zanetti, 1995).

General distribution. Europe, Near East, Northern India (Schülke \& Smetana, 2015).

Habitat. Eurytopic, often in nests of birds (Koch, 1989).

Aleochara stichai Likovský, 1965

Detection area: PNC Motola.

Distribution in Italy. Not very well-known distribution, the species is recorded from northern Italy by Zanetti (1995).

General distribution. Europe and Turkey (Schülke \& Smetana, 2015).

Habitat. In decomposing materials (Koch, 1989).

Alevonota egregia (Rye, 1876)

Detection area: PNGS Venacquaro.

Distribution in Italy. Recorded from various localities of northern Italy and Basilicata (Assing \& Wunderle, 2008).

General distribution. According to Assing \& Wunderle (2008), it has Ponto-Mediterranean distribution.

Habitat. Primary habitat unknown, often captured in fly (Assing \& Wunderle, 2008).

Anotylus sculpturatus (Gravenhorst, 1806)

Detection area: PNC Motola.

Distribution in Italy. All continental Italy and major islands (Ciceroni et al., 1995).

General distribution. Europe, North Africa, Near East and Central Asia (Schülke \& Smetana, 2015).

Habitat. Eurytopic, in excrements and decaying plants (Koch, 1989).

Anthophagus fauveli caprai Koch, 1933

Detection area: PNC Alburni: Ottati; PNGS Incodara, Prati di Tivo, Venacquaro.

Distribution in Italy. Apennine (A. f. caprai Koch, 1933) and Sicily (A.f. fauveli Luze, 1902).

General distribution. Apennines (Zanetti, 1987). On the vegetation (Zanetti, 1987).

Anthophagus torretassoi torretassoi Koch, 1933

Detection area: PNGS Prati di Tivo.

Distribution in Italy. Central (A.t. torretassoi Koch, 1933) and Southern (A.t. pollinensis Koch, 1934) Apennines.

General distribution. Apennines. On the herbaceous and shrubby vegetation (Zanetti, 1987). 
Tab. 1. List of Staphylinid species in alphabetic order.

Column eco: the ecology of species as follows: fl: on flowers; myc: on fungi; nid: in nests; prat: in open areas; rip: on banks; sap: in decaying matters; silv: in forests; sx: saproxylic; uk: unknown. Column IUCN: category (for saproxylic species only); other columns: presence in PNC and/or PNCS in 2013 and/or 2016.

\begin{tabular}{|c|c|c|c|c|c|c|}
\hline Species & eco & IUCN & $\mathrm{PNC}$ & PNGS & PNC & PNGS \\
\hline & & & 2013 & 2013 & 2016 & 2016 \\
\hline Aleochara intricata Mannerheim, 1830 & sap & & & & 1 & \\
\hline Aleochara sparsa Heer, 1839 & sap & & & & 1 & 1 \\
\hline Aleochara stichai Likovský, 1965 & sap & & & & 1 & \\
\hline Alevonota egregia $($ Rye, 1876$)$ & $\mathrm{uk}$ & & & & & 1 \\
\hline Anotylus sculpturatus (Gravenhorst, 1806) & sap & & & & 1 & \\
\hline Anthophagus fauveli caprai Koch, 1933 & $\mathrm{fl}$ & & 3 & 4 & & 5 \\
\hline Anthophagus torretassoi torretassoi Koch, 1933 & fl & & & 1 & & \\
\hline Atheta castanoptera (Mannerheim, 1830) & myc & & & & 1 & \\
\hline Atheta crassicornis (Fabricius, 1793) & myc & & & & 3 & \\
\hline Atheta longicornis (Gravenhorst, 1802) & sap & & & & 1 & \\
\hline Atheta taxiceroides Munster, 1932 & $\mathrm{uk}$ & & & & 4 & 1 \\
\hline Atrecus affinis (Paykull, 1789) & sx & $\mathrm{LC}$ & 1 & 1 & & 1 \\
\hline Bisnius fimetarius (Gravenhorst, 1802) & sap & & & & 1 & \\
\hline Dinothenarus flavocephalus flavocephalus (Goeze, 17 & sap & & 1 & & & \\
\hline Eusphalerum bargagli (Luze, 1910) & $\mathrm{fl}$ & & & 1 & & \\
\hline Eusphalerum baudii (Fiori, 1894) & fl & & 14 & & 1 & \\
\hline Eusphalerum clavipes (Scriba, 1868) & fl & & & & & 2 \\
\hline Eusphalerum italicum italicum (Koch, 1938) & fl & & & 2 & & 1 \\
\hline Eusphalerum martinae (Zanetti, 2004) & fl & & 4 & & & \\
\hline Eusphalerum signatum angulatum (Luze, 1911) & fl & & 4 & 18 & 13 & 9 \\
\hline Gyrohypnus angustatus Stephens, 1833 & prat & & & & 2 & 1 \\
\hline Gyrohypnus fracticornis (Müller, 1776) & sap & & 1 & & & \\
\hline Habrocerus capillaricornis (Gravenhorst, 1806) & silv & & & & & 1 \\
\hline Haploglossa $\mathrm{cf}$. picipennis (Gyllenhal, 1827) & nid & & & & 1 & \\
\hline Lordithon lunulatus (Linneus, 1760) & myc & & 1 & & 2 & 2 \\
\hline Neuraphes sp. & uk & & 1 & & & \\
\hline Ocypus italicus (Aragona, 1830) & silv & & & & 2 & 2 \\
\hline Ontholestes murinus (Linnaeus, 1758) & sap & & & & 1 & \\
\hline Paraphloeostiba gayndahensis (MacLeay, 1873) & sap & & & & & 1 \\
\hline Philonthus carbonarius (Gravenhorst, 1802) & prat & & & & 1 & \\
\hline Philonthus cognatus (Stephens, 1832) & prat & & 1 & & & \\
\hline Philonthus concinnus (Gravenhorst, 1822) & sap & & 1 & & & \\
\hline Philonthus decorus (Gravenhorst, 1802) & silv & & 1 & 1 & & 1 \\
\hline Philonthus laminatus (Creutzer, 1799) & prat & & & 1 & & \\
\hline Philonthus mannerheimi Fauvel, 1869 & prat & & & & & 1 \\
\hline Philonthus succicola (Thomson, 1860) & sap & & 1 & & & \\
\hline Phloeopora corticalis corticalis (Gravenhorst, 1802) & sx & $\mathrm{LC}$ & & & & 1 \\
\hline Phloeostiba plana (Paykull, 1792) & sx & $\mathrm{LC}$ & & & & 2 \\
\hline Platystethus nitens (Sahlberg, 1832) & prat & & 1 & & & \\
\hline Pseudopsis sulcata Newman, 1834 & silv & & & & & 1 \\
\hline Quedius boops (Gravenhorst, 1802) & prat & & & & 3 & \\
\hline Quedius cinctus (Paykull, 1790) & sap & & 3 & 1 & & \\
\hline Quedius humeralis (Stephens, 1832) & silv & & 2 & & & \\
\hline Quedius italicus Gridelli, 1925 & silv & & & 1 & & 1 \\
\hline Quedius latialis Gridelli, 1924 & sx & & & & & 2 \\
\hline Quedius levicollis (Brullé, 1832) & prat & & 1 & & & \\
\hline Quedius nigrocaeruleus (Fauvel, 1876) & nid & & 1 & & & \\
\hline Quedius picipes (Mannerheim, 1830) & prat & & 1 & & & \\
\hline Quedius riparius (Kellner, 1843) & rip & & & & & 1 \\
\hline Quedius truncicola Fairmaire \& Laboulbène, 1856 & $\mathrm{Sx}$ & & & & 1 & \\
\hline Tachinus humeralis humeralis Gravenhorst, 1802 & sap & & & 1 & & \\
\hline Tachinus rufipes ( Linnaeus, 1758) & sap & & & & & 1 \\
\hline Tachyporus nitidulus (Fabricius, 1781) & prat & & 1 & & 4 & \\
\hline Thamiaraea cinnamomea (Gravenhorst, 1802) & sx & & & & 1 & \\
\hline
\end{tabular}


Atheta castanoptera (Mannerheim, 1830)

Detection area: PNC Motola.

Distribution in Italy. All continental Italy and major islands (Zanetti, 1995).

General distribution. Palearctic region (Schülke \& Smetana, 2015).

Habitat. Eurytopic mostly on fungi (Koch, 1989).

Atheta crassicornis (Fabricius, 1793)

Detection area: PNC Motola.

Distribution in Italy. All continental Italy and major islands (Zanetti, 1995).

General distribution. Europe, North Africa, and Central Asia (Schülke \& Smetana, 2015).

Habitat. Eurytopic mostly on fungi (Koch, 1989).

Atheta longicornis (Gravenhorst, 1802)

Detection area: PNC Alburni: Ottati.

Distribution in Italy. All continental Italy and major islands (Zanetti, 1995).

General distribution. Subcosmopolitan (Schülke \& Smetana, 2015).

Habitat. Eurytopic in decaying matters (Koch, 1989).

Atheta taxiceroides Munster, 1932

Detection area: PNC Alburni: Ottati; PNGS Prati di Tivo.

Distribution in Italy. Until today known only for a few localities in the Apennines (Alpe della Luna, Arezzo, Tagliapietra \& Zanetti, 2003).

General distribution. Europe, especially in the centralnorthern regions (Schülke \& Smetana, 2015).

Habitat. In forests, microhabitat unknown (Tagliapietra \& Zanetti, 2003).

\section{Atrecus affinis (Paykull, 1789)}

Detection area: PNC Alburni: Corleto Monforte; PNGS Prati di Tivo, Venacquaro

Distribution in Italy. Central-Northern Italy and Sicily (Ciceroni \& Zanetti, 1995).

General distribution. Europe, Turkey, also recorded from Eastern Siberia (Schülke \& Smetana, 2015).

Habitat. Eurytopic in decaying wood (Koch, 1989).

Bisnius fimetarius (Gravenhorst, 1802)

Detection area: PNC Alburni: Ottati.

Distribution in Italy. All continental Italy and major islands (Ciceroni \& Zanetti, 1995).
General distribution. Palearctic region, imported into North America (Schülke \& Smetana, 2015).

Habitat. Eurytopic in decaying matters (Koch, 1989).

Dinothenarus flavocephalus flavocephalus (Goeze, 1777)

Detection area: PNC Alburni: Ottati.

Distribution in Italy. Apennines, Sicily and Sardinia (Ciceroni \& Zanetti, 1995).

General distribution. Southern Europe, Turkey, D. $f$. adonis (Coiffait, 1956) in the Near East (Turkey, Iraq, Israel, Lebanon, Syrie, Turkey) (Schülke \& Smetana, 2015).

Habitat. In decaying matters (Pilon, 2005).

Eusphalerum bargaglii (Luze, 1910)

Detection area: PNGS Incodara.

Distribution in Italy. From the central Alps to Calabria (Zanetti, 2005).

General distribution. Mainland Italy and, also, some French and Swiss localities.

Habitat. On flowers, mostly of shrubby Rosaceae (Zanetti, 1987).

Eusphalerum baudii (Flowers, 1894)

Detection area: PNC Alburni: Corleto Monforte.

Distribution in Italy. Central Southern Apennines, from the Marche to Calabria (Zanetti, 2005).

General distribution. Apennines.

Habitat. On flowers of several plants (Zanetti, 1987).

Euspahlerum clavipes (W. Scriba, 1868)

Detection area: PNGS Incodara, Venacquaro.

Distribution in Italy. From the Maritime Alps to the central Apennines (Zanetti, 2005).

General distribution. Mainland Italy.

Habitat. On flowers, mostly Fabaceae (Genista pilosa, Citysus scoparius) (Zanetti, 1987).

Eusphalerum italicum italicum (Koch, 1938)

Detection area: PNGS Incodara, Prati di Tivo, Venacquaro.

Distribution in Italy. The Apennines from Emilia to Puglia (various subspecies of high altitude), thermophile areas of the southern Prealps (Zanetti, 2005). General distribution. Mainland Italy (Zanetti, 2005).

Habitat. On flowers mostly of shrubby Rosaceae (Prunus, Crataegus, Amelanchier). Peculiar populations with dark, brown colour, live in the Apennines 
at high altitude on herbaceous plants (e.g. Cerastium, Doronicum) (Eusphalerum italicum binaghii Zanetti, 1980, E. i. audisioi Zanetti, 1980 and unpublished records and Zanetti, 1987).

Eusphalerum martinae (Zanetti, 2004)

Detection area: PNC Alburni: Ottati.

Distribution in Italy. Few places in Basilicata and Campania (Zanetti, 2004).

General distribution. Central-Southern Italy (Basilicata and Campania) Italy (Zanetti, 2004).

Habitat. On flowers, mostly of Prunus sp. (Zanetti, 2004).

Eusphalerum signatum angulatum (Luze, 1911) Detection area: PNC Alburni: Ottati; PNGS Incodara, Prati di Tivo, Venacquaro.

Distribution in Italy. E. s. angulatum is widespread in the Western Alps and in the Apennines up to southern Calabria, in the rest of the Alps E. s. signatum (Märkel, 1857) is found (Zanetti, 1995, 2005).

General distribution. Central Europe, Italy (Zanetti, 1987).

Habitat. On flowers, mostly on trees and shrubs (Rosaceae, Salix) (Zanetti, 1987).

Gyrohypnus angustatus Stephens, 1833

Detection area: PNC Alburni: Ottati; PNGS Venacquaro.

Distribution in Italy. Throughout Italy and the major islands (Ciceroni \& Zanetti, 1995).

General distribution. Palearctic Region, North America (imported) (Schülke \& Smetana, 2015).

Habitat. Eurytopic in vegetal debris (Koch, 1989).

Gyrohypnus fracticornis (Müller, 1776)

Detection area: PNC Alburni: Corleto Monforte.

Distribution in Italy. All Italy and major islands (Ciceroni \& Zanetti, 1995).

General distribution. A large part of the Palaearctic region, imported into Australia and the Nearctic and Neotropical regions (Schülke \& Smetana, 2015).

Habitat. In excrements and vegetal decaying matters (Koch, 1989).

Habrocerus capillaricornis (Gravenhorst, 1806)

Detection area: PNGS Incodara.

Distribution in Italy. All Italy and major islands (Zanetti, 1995).
General distribution. Europe, North Africa, Near East, introduced in the Afrotropical, Nearctic and Neotropical regions (Schülke \& Smetana, 2015).

Habitat. Eurytopic in vegetal debris (Koch, 1989).

Haploglossa picipennis (Gyllenhal, 1827)

Detection area: PNC Alburni: Ottati.

Distribution in Italy. Northern Italy, while the record from Sardinia (Zanetti, 1995), must be confirmed. General distribution. Europe and Eastern Siberia (Schülke \& Smetana, 2015).

Habitat. In nests of birds (Koch, 1989).

Note. The identification of the sole collected specimen is doubt.

Lordithon lunulatus (Linnaeus, 1760)

Detection area: PNC Alburni: Ottati, Corleto Monforte; PMGS Venacquaro.

Distribution in Italy. Continental Italy and Sardinia (Zanetti, 1995).

General distribution. Europe and Siberia (Schülke \& Smetana, 2015).

Habitat. On fungi (macromycetes) (Koch, 1989).

Neuraphes sp.

Detection area: PNC Alburni: Ottati.

Distribution in Italy. -

General distribution. -

Habitat. Not known.

\section{Ocypus italicus (Aragona, 1830)}

Detection area: PNC Alburni: Ottati; PNGS Incodara, Venacquaro.

Distribution in Italy. From the Cuneo province (Piedmont) to Aspromonte (Calabria) (Pilon, 2005).

General distribution. Italy and some localities of the French Western Alps (Tronquet, 2014).

Habitat. Vegetal debris in any kind of forest (Zanetti \& Tagliapietra, 2005).

Ontholestes murinus (Linnaeus, 1758)

Detection area: PNC Alburni: Ottati.

Distribution in Italy. All continental Italy and Sicily, doubtful in Sardinia (Ciceroni \& Zanetti, 1995).

General distribution. Europe, Palearctic areas of Asia, introduced in North America but possibly not established (Klimaszewski et al., 2013, Schülke \& Smetana, 2015).

Habitat. In any kind of decaying matters (Koch, 1989). 
Paraphloeostiba gayndahensis (MacLeay, 1873)

Detection area: PNGS Venacquaro.

Distribution in Italy. Most of mainland Regions and Sicily (Zanetti, 2005).

General distribution. Species native of Australia, it has been introduced almost all over the world (Schülke \& Smetana, 2015).

Habitat. Eurytopic in decaying matters, mostly vegetal (Zanetti, 2005).

\section{Philonthus carbonarius (Gravenhorst, 1802)}

Detection area: PNC Alburni: Ottati.

Distribution in Italy. All continental Italy and major islands (Ciceroni \& Zanetti, 1995).

General distribution. Palearctic region, introduced in North America (Schülke \& Smetana, 2015).

Habitat. Eurytopic in vegetal debris (Koch, 1989).

Philonthus cognatus (Stephens, 1832)

Detection area: PNC Alburni.: Corleto Monforte.

Distribution in Italy. All continental Italy and major islands (Ciceroni \& Zanetti, 1995).

General distribution. Palearctic region, introduced in North America (Schülke \& Smetana, 2015).

Habitat. Eurytopic in vegetal debris (Koch, 1989).

Philonthus concinnus (Gravenhorst, 1822)

Detection area: PNC Alburni: Corleto Monforte.

Distribution in Italy. All continental Italy and major islands (Ciceroni \& Zanetti, 1995).

General distribution. Palearctic region, introduced in North America (Schülke \& Smetana, 2015).

Habitat. Eurytopic in decaying matters (Koch, 1989).

Philonthus decorus (Gravenhorst, 1802)

Detection area: PNC Alburni: Corleto Monforte; PNGS Prati di Tivo, Venacquaro.

Distribution in Italy. All continental Italy and major islands (Ciceroni \& Zanetti, 1995).

General distribution. Europe, Kazakhstan, Siberia, introduced in the Canary Islands (Schülke \& Smetana, 2015).

Habitat. In forests in vegetal debris (Koch, 1989).

Philonthus laminatus (Creutzer, 1799)

Detection area: PNGS Incodara.

Distribution in Italy. All continental Italy and major islands (Ciceroni \& Zanetti, 1995).
General distribution. Europe and Central Asia (Schülke \& Smetana, 2015).

Habitat. Eurytopic in decaying matters (Koch, 1989).

Philonthus mannerheimi Fauvel, 1869

Detection area: PNGS Venacquaro.

Distribution in Italy. Until now it was known in Northern Italy and, doubtfully, in peninsular Italy (Ciceroni \& Zanetti, 1995).

General distribution. Europe and Western Siberia (Schülke \& Smetana, 2015).

Habitat. In wet open places in vegetal debris (Koch, 1989).

Note. We also know a capture in PNC: Rofrano (Salerno), Campolongo loc., $750 \mathrm{~m}, 30.04 .2015$,

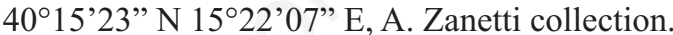

Philonthus succicola (Thomson, 1860)

Detection area: PNC Motola.

Distribution in Italy. Continental Italy and Sicily (Ciceroni \& Zanetti, 1995).

General distribution. Europe and Palearctic Asia (Schülke \& Smetana, 2015).

Habitat. Eurytopic in decaying matters (Koch, 1989).

Phloeopora corticalis corticalis (Gravenhorst, 1802) Detection area: PNGS Incodara, Venacquaro.

Distribution in Italy. Not clearly known.

General distribution. Europe (Spain excepted), North Africa and Turkey, P. c. occidentalis Newton, 2015 in Spain.

Habitat. Under barks, mostly of broad-leaved trees (Koch, 1989, as P. angustiformis).

Phloeostiba plana (Paykull, 1792)

Detection area: PNGS Incodara.

Distribution in Italy. Continental Italy and Sicily (Zanetti, 2005).

General distribution. Europe and Palearctic Asia (Schülke \& Smetana, 2015).

Habitat. Under barks of broad-leaved trees (Zanetti, 1987).

Platystethus nitens (Sahlberg, 1832)

Detection area: PNC Alburni: Ottati.

Distribution in Italy. All Italy and major islands (Ciceroni \& Zanetti, 1995).

General distribution. Palearctic region (Schülke \& Smetana, 2015).

Habitat. Eurytopic in wet places (Koch, 1989). 
Pseudopsis sulcata Newman, 1834

Detection area: PNGS Venacquaro.

Distribution in Italy. Apennines (Zanetti, 1995) and

Sardinia (Herman, 1975).

General distribution. Europe, North Africa and Near East.

Habitat. In Italy in forest in vegetal debris, in central Europe synanthropic (Koch, 1989).

Quedius boops (Gravenhorst, 1802)

Detection area: PNC Alburni: Ottati.

Distribution in Italy. Northern and central-southern Italy and Sicily (Ciceroni \& Zanetti, 1995).

General distribution. Europe, North Africa and Western Siberia, Q. b. islandicus Fagel, 1960 from Iceland (Schülke \& Smetana, 2015) is now considered as a synonym of $Q$. boops (Assing, 2017).

Habitat. Eurytopic in vegetal debris (Koch, 1989).

\section{Quedius cinctus (Paykull, 1790)}

Detection area: PNC Alburni, Motola; PNGS Venacquaro.

Distribution in Italy. All Italy and major islands (Ciceroni \& Zanetti, 1995).

General distribution. Europe, Near East, introduced in North America (Schülke \& Smetana, 2015).

Habitat. Eurytopic in decaying matters (Koch, 1989).

Quedius humeralis (Stephens, 1832)

Detection area: PNC Alburni: Corleto Monforte.

Distribution in Italy. All Italy and major islands (Ciceroni \& Zanetti, 1995).

General distribution. Europe, Turkey and Uzbekistan (Schülke \& Smetana, 2015).

Habitat. In forests in vegetal debris (Koch, 1989).

\section{Quedius italicus Gridelli, 1925}

Detection area: PNGS Incodara, Venacquaro.

Distribution in Italy. Central-western Alps and Apennines southward to Calabria (Ciceroni \& Zanetti, 1995, Assing, 2016).

General distribution. Italy and some places in the Alpes de Provence in France (Assing 2016).

Habitat. In forests in vegetal debris (Assing, 2016).

Note. It is recently raised to species level, previously it was considered a subspecies of $Q$. collaris Erichson, 1840 (Assing, 2016).
Quedius latialis Gridelli, 1924

Detection area: PNGS Venacquaro, Prati di Tivo.

Distribution in Italy. Endemic of the Central Apennines and vicariate by the very similar $Q$. bruttius Zanetti, 1977 in Southern Regions (Basilicata and Calabria) (Zanetti, 1977, Ciceroni \& Zanetti, 1995).

General distribution. Italian endemic.

Habitat. The habitat of the species is not clearly documented, but its aedeagus is asymmetrical and this feature is typical of saproxylic Quedius (Microsaurus) species.

\section{Quedius levicollis (Brullé, 1832)}

Detection area: PNC Alburni: Corleto Monforte.

Distribution in Italy. All continental Italy and major islands (Ciceroni \& Zanetti, 1995).

General distribution. Europe, North Africa, Near East (Schülke \& Smetana, 2015).

Habitat. In vegetal debris in warm areas (Koch, 1989).

Quedius nigrocaeruleus (Fauvel, 1876)

Detection area: PNC Motola.

Distribution in Italy. All continental Italy and major islands (Ciceroni \& Zanetti, 1995).

General distribution. Europe (Schülke \& Smetana, 2015).

Habitat. In nests of small mammals (Koch, 1989).

Quedius picipes (Mannerheim, 1830)

Detection area: PNC Alburni: Corleto Monforte.

Distribution in Italy. Continental Italy and Sicily (Ciceroni \& Zanetti, 1995).

General distribution. Europe and Western Siberia (Schülke \& Smetana, 2015).

Habitat. Eurytopic in vegetal debris (Koch, 1989).

Quedius riparius Kellner, 1843

Detection area: PNGS Incodara.

Distribution in Italy. Northern Italy (Ciceroni \& Zanetti, 1995), and the Apennines (Osella et al., 2009). General distribution. Europe and Near East (Schülke \& Smetana, 2015).

Habitat. A riparian species living in moss (Koch, 1989), rare.

Quedius truncicola Fairmaire \& Laboulbène, 1856 Detection area: PNC Motola.

Distribution in Italy. Northern and central-southern Italy and Sicily (Ciceroni \& Zanetti, 1995; Parisi et al., 2016). 
General distribution. Europe (Schülke \& Smetana, 2015).

Habitat. In tree holes (Koch, 1989).

Tachinus humeralis humeralis Gravenhorst, 1802 Detection area: PNGS Venacquaro.

Distribution in Italy. Continental Italy and Sicily (Zanetti, 1995).

General distribution. Europe and the Near East, $T . h$. marginicollis Kolenati, 1846 in Azerbaijan, Georgia, Iran and Turkey (Schülke \& Smetana, 2015).

Habitat. Eurytopic in decaying matters in warm places (Koch, 1989).

Tachinus rufipes (Linnaeus, 1758)

Detection area: PNGS Venacquaro.

Distribution in Italy. All continental Italy and major islands (Zanetti, 1995).

General distribution. Palearctic Region, introduced in North America (Schülke \& Smetana, 2015).

Habitat. Eurytopic in decaying matters (Koch, 1989).

Tachyporus nitidulus (Fabricius, 1781)

Detection area: PNC Alburni; Ottati, Corleto Monforte; Motola.

Distribution in Italy. All continental Italy and major islands (Zanetti, 1995).

General distribution. Subcosmopolitan. Palaeartic species introduced in Australia and in the Neartic region (Schülke \& Smetana, 2015).

Habitat. Eurytopic in vegetal debis (Koch, 1989).

Thamiaraea cinnamomea (Gravenhorst, 1802)

Detection area: PNC Alburni: Ottati.

Distribution in Italy. Northern Italy and the Apennines, Sicily (Zanetti, 1995).

General distribution. Europe (Schülke \& Smetana, 2015).

Habitat. In the fermenting sap of trees (Koch, 1989).

Comments on the species collected. Species were attributed to ecological classes according to their habitat preferences. In some cases, habitats are to be regarded as macro habitats (forests, open lands) and then species live in the litter, in other as microhabitats (flowers, fungi, nests, decaying matters, tree holes) and in these cases macrohabitat is scarcely influent. Fig. 1 represents the percent of the single classes in the sampled species. No class is clearly dominant in
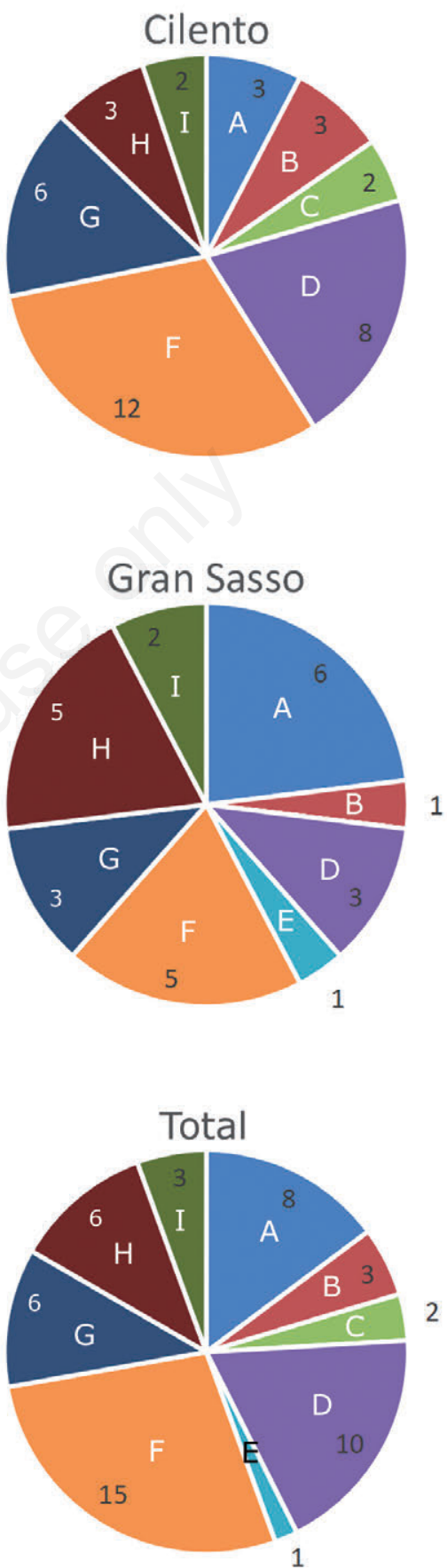

Fig 1. Pie charts representing percentage of species for each preferential habitat in the two areas (Cilento, Gran Sasso) and in total. Letters in charts mean as follows: A: species living on flowers; B: species living on fungi; C: species living in nests; $\mathrm{D}$ : species living in open habitats; E: species living on banks; F species living in decaying matters; $G$ : species living in forests; H: saproxylic species; I: ecology unknown. 
all cases, and the frequency in the traps seems to be related more to the mobility of single species than to their habitat preference.

Regarding saproxylic species, they represent the $11 \%$ of the total. The presence of species rare (Quedius truncicola) and/or scarcely known (Q. latialis) is ecologically significant.

\section{CONCLUSIONS}

The following general remarks on the sampled material can be done: i) the total number of sampled species (54) is adequate to represent the features of the Staphylinid community in the areas, with special reference to those with high mobility; ii) species are most widely distributed, most of the endemic entities (11) are linked to the aerial part of the vegetation (flowers and leaves); iii) saproxylic species are scarcely represented, but include some relevant taxa.

\section{ACKNOWLEDGMENTS}

This project was funded under the LIFE+ project (11/NAT/IT/00135) FAGUS: 'Forests of the Apennines: Good practices to conjugate Use and Sustainability' http://www.faguslife- project.eu/. Coordinating beneficiary: Cilento Vallo di Diano and Alburni National Park. Associated beneficiaries: Gran Sasso and Monti della Laga National Park; Department of Environmental Biology, Sapienza, University of Rome; Department for Innovation in Biological, Agro-food and Forest systems, University of Tuscia.

We are grateful to Marco Marchetti, Roberto Tognetti, Antonio De Cristofaro, Massimo Mancini (Università degli Studi del Molise), Fabio Lombardi (Università Mediterranea di Reggio Calabria), Sabina Burrascano (Università di Roma La Sapienza) for their support.

\section{REFERENCES}

AssING V. 2016 - On the taxonomy and zoogeography of the species of the Quedius paradisianus group (Coleoptera: Staphylinidae: Staphylininae). Entomologische Blätter und Coleoptera, 112 (2): 65-83.

Assing V., 2017 - On the micropterous Quedius (Raphirus) species with a punctate scutellum of Turkey (Coleoptera: Staphylinidae: Staphylininae). Linzer biologische Beiträge, 49(2): 1029-1039.

Assing V., WUNDERLE P., 2008 - On the Alevonota species of the Western Palaearctic region (Coleoptera: Staphylinidae: Aleocharinae: Athetini). Beiträge zur Entomologie, 58: 145-189.

Ciceroni A., ZANETTI A., 1995 - Coleoptera Polyphaga III. 48 Coleoptera Staphylinidae Oxytelinae (generi 047-061), Paederinae e Staphylininae (generi 079-147). In: Minelli A., Ruffo S., La Posta S. (eds.). Checklist delle specie della fauna Italiana, 48. Calderini, Bologna.

Herman L.H. JR., 1975 - Revision and phylogeny of the monogeneric subfamily Pseudopsinae of the world (Staphylinidae, Coleoptera). Bulletin of the American Museum of Natural History, 155(3): 243-316.

Klimaszewski J, Brunke A., Assing V., Langor D.W., Newton A., Bourdon C., Pellitier G., Webster R.P., Herman L., Perdereau L., Davies A., Smetana A., Chandler D.S., Majka C., Scudder G.G.E, 2013 - Synopsis of adventive species of Coleoptera (Insecta) recorded from Canada. Part 2: Staphylinidae. Pensoft, Sofia-Moscow, 360 pp.

Kосн K., 1989 - Die Käfer Mitteleuropas, Ökologie. Vol. 1. Goecke \& Evers, Krefeld, 382 pp.

Mattioli W., Di Santo D., Barbati A., Portoghesi L., Burrascano S., Sabatini F.M., Giuliarelli D., 2017 - Manuale di buone pratiche per la gestione degli habitat 9210* e 9220*. Parco Nazionale del Cilento, Vallo di Diano e Alburni Centro Studi Naturalistici Onlus: 1-71.

Osella G., Pannunzio G., Zanetti A., 2009 - Il popolamento ad Artropodi dei muschi igropetrici del Parco Nazionale del Gran Sasso d'Italia e Monti della Laga. Bollettino del Museo Civico di Storia Naturale di Verona, 33, Botanica Zoologia, 3-26.

Parisi F., Campanaro A., Di Febbraro M., Audisio P., Biscaccianti A.B., Colonnelli E., Faccoli M., Fanti F., Latella L., Nardi G., Piattella E., Platia G., Poggi R., Ruzzier E., Vigna Taglianti A., Zanetti A., Marchetti A., 2017 Characterization of the saproxylic communities of a fir and a Turkey oak forest in Central Italy: faunistic and conservation insights. European Workshop, Monitoring of saproxylic beetles and other insects protected in the European Union, 24th - 26th May 2017, Mantova Italy. Programme \& Abstract book: 32.

Pilon N., 2005 - Insecta Coleoptera Staphylinidae Staphylininae, pp. 187-188 + CD-ROM. In: Ruffo S. \& Stoch F. (eds). Checklist e distribuzione della fauna italiana. 10.000 specie terrestri e delle acque interne. Memorie del Museo civico di Storia Naturale di Verona, 2. Serie, Sezione Scienze della Vita, 16. [Data bank available also on http://www.minambiente.it/index.php]

Sabella G., Zanetti A., 1991 - Studi sulle comunità a Coleotteri Stafilinidi dei Monti Nebrodi (Sicilia) (1 ${ }^{\circ}$ contributo). Animalia, 18: 269-297. 
Sabatini F.M., Burrascano S., Azzella M.M., Barbati A., De Paulis S., Di Santo D., Facioni L., Giuliarelli D., Lombard F., Maggi O., Mattioli W., Parisi F., Persiani A., Ravera S., Blasi C., 2016 - One taxon does not fit all: Herb-layer diversity and stand structural complexity are weak predictors of biodiversity in Fagus sylvatica forests. Ecological Indicators, 69: 126-137.

SchÜlke M., Smetana A., 2015 - Staphylinidae. In: LöBl I., LöBl D., 2015 (eds). Catalogue of Palaearctic Coleoptera volume 2/1 and 2/2. Hydrophiloidea-Staphylinoidea revised and updated Edition. Brill, Leiden-Boston, $1702 \mathrm{pp}$.

Tagliapietra A., Zanetti A., 2003 - Staphylinidae. In: Cerretti P., Tagliapietra A., Tisato M., Vanin S., Mason F., Zapparoli M. (EDS.). Artropodi dell'orizzonte del faggio nell'Appennino settentrionale - primo contributo. Conservazione Habitat Invertebrati 2. Gianluigi Arcari Editore, Mantova, 256 pp.

Zanetti A., TAgliapietra A., 2005 - Studi sulle taxocenosi a Staphylininae in boschi di latifoglie italiani (Coleoptera, Staphylinidae). Studi trentini Scienze Naturali Acta Biologica, 81 (2004): 207-231.

ZANetri A., 1977 - Due nuove specie di Stafilinidi (Coleoptera) dell'Appennino. Bollettino del Museo civico di Storia naturale di Verona, 4: 307-315.

Zanetti A., 1987 - Fauna d'Italia XXV. Coleoptera Staphylinidae Omaliinae. Calderini, Bologna, 472 pp.

Zanetti A., 1995 - Coleoptera Polyphaga III. 48 Coleoptera Staphylinidae Pseudopsinae, Omaliinae (generi 001-046), Habrocerinae, Tachyporinae e Aleocharinae (generi 148-314). In: Minelli A., Ruffo S., LA Posta S. (eds.). Checklist delle specie della fauna Italiana, 48. Calderini, Bologna.

ZANETti A., 2004 - Eusphalerum martinae n. sp. from southern Italy (Coleoptera, Staphylinidae: Omaliinae). Bollettino del Museo regionale di Scienze naturali di Torino, 21(2): 487-494.

ZANETti A., 2005 - Insecta Coleoptera Staphylinidae Omaliinae. In: Ruffo S., Stoch F. (eds.), Checklist e distribuzione della fauna italiana. Memorie del Museo Civico di Storia naturale di Verona, 2. ser., Sezione Scienze della Vita, 16: 185-186. [Data bank available also on http://www.minambiente.it/index.php]

ZANETTI A., 2015 - Second contribution to the knowledge of the rove beetles (Coleoptera: Staphylinidae) of Val di Non / Nonstal (Trentino / Südtirol, Italy). Gredleriana, 15: 77-109. 